Said carrier shall obtain receipts by name, or, if the person be unknown, by a description, for each body delivered by him, and shall deposit said receipt with the secretary of the said board.

SEc. 5. No school, college, physician, or surgeon shall be allowed or permitted to receive any such body or bodies until a bond shall have been given to the Commonwealth by such physician or surgeon, or by or in behalf of such school or college, to be approved by the Prothonotary of the Court of Common Pleas in and for the county in which such physician or surgeon shall reside, or in which such school or college may be situate, and to be filed in the office of said Prothonotary, which bond shall be in the penal sum of one thousand dollars, conditioned that all such bodies which the said physician or surgeon, or the said school or college, shall receive thereafter shall be used only for the promotion of medical science within the State; and whosoever shall sell or buy such body or bodies, or in any way traffic in the same, or shall transmit, or convey, or cause to procure to be transmitted or conveyed said body or bodies to any place outside of this State shall be deemed guilty of a misdemeanor, and shall, on conviction, be liable to a fine not exceeding two hundred dollars, or be imprisoned for a term not exceeding one year.

SEc. 6. Neither the Commonwealth, nor any county or municipality, nor any officer, agent, or servant thereof, shall be at any expense by reason of the delivery or distribution of any such body, but all the expenses thereof, and of said board of distribution, shall be paid by those receiving the bodies, in such manner as may be specified by said board of distribution, or otherwise agreed upon.

SEc. 7. That any person having duties enjoined upon him by the provisions of this Act, who shall neglect, refuse, or omit to perform the same as hereby required, shall, on conviction thereof, be liable to fine of not less than one hundred nor more than five hundred dollars, for each offence.

SEC. 8. That all Acts or parts of Acts inconsistent with this Act be and the same are hereby repealed.

Philadelphia, January 1, 1889.

In accordance with the requirements of the above law the Anatomical Board of the State of Pennsylvania was organized July, 1883 , for the purpose of carrying it into execution. The attention of all State, county and municipal officers charged with duties under the law is directed to its requirements. Boxes containing bodies should be addressed to George Willie, Philadelphia, and should be delivered to the agent of the express company at the station nearest to the place from which the body is sent. The charges paid by the Board for transportion to the railroad station vary from $\$ 1.00$ to $\$ 2.50$ in accordance with the distance. These charges will be paid by the agent of the express company, and collected from the Board by the agent in Philadelphia.

\section{SEVENTH ANNUAL MEETING OF THE AMERICAN FOLK-LORE SOCIETY.}

THe American Folk-lore Society held its seventh annual meeting in Philadelphia on Friday and Saturday, December 27 and 28, 1895. Although the attendance was rather slim, the number and the value of the papers presented made the session an interesting one. The President, Dr. Washington Matthews, opened the meeting with an address on the poetry and music of the Navahoes. He brought out very clearly the misconception of superficial observers who have not had the opportunity to enter into the spirit of Indian life, and consequently described the primitive tribes as void of poetic or musical feeling. The examples given by the speaker are ample proof that the Nava- 
hoes possess a well-developed poetry. In a supplementary paper by Professor J. C. Fillmore the characteristics of Navahoe music were described, which showed that in this case also harmony is the underlying principle of primitive music.

Dr. Robert Bell, the indefatigable explorer, to whose zeal we owe much of our knowledge of the topography and geology of northern Canada, related five Algonquin myths which he collected in the region between Ottawa River and Hudson Bay. These have their close analoga among other tribes of the same stock. Magic and medicine came in for a considerable share of attention in the papers read on the first day of the proceedings. Mr. Stanbury T. Hagar treated the Micmac of Nova Scotia from this point of view, while Dr. J. H. McCormick described the medicine myths of the Cherokee, and Mr. Heli Chatelain made an interesting contribution on the customs of the natives of West Africa.

On the second day a number of papers were read referring to current superstitions of the whites in America. Mr. Robert $\mathbf{M}$. Lawrence presented a vast amount of information on the folk-lore of the horseshoe, in which he dwelt upon the superstitions, referring to its form and material, and those referring to the place at which the horseshoe is used in order to secure good luck. Mr. W. W. Newell contributed a review of a collection on moon superstitions in America made by Mrs. Fanny Bergen. Dr. D. G. Brinton showed how the tendency to displace sacred words by others has led to a curious development of 'cuss words' in America.

A very comprehensive review of the customs of the Spanish in the Rio Grande Valley was presented in a paper by Captain John Bourke on 'Arabic Survivals in the Rio Grande Valley.' Dr. F. Boas discussed the dissemination of tales in America, basing his argument on a comparative study of the myths of the Indians of the North Pacific Coast. A noteworthy myth of the Navahoes was told by Dr. Matthews, in which the principle underlying the secret societies of this tribe was brought forward most clearly. This seems to be identical among all the tribes of North America: An ancestor of the Indians is taken away by certain supernatural beings and is taught by them the secrets and particularly the songs of the society. In conclusion, Dr. McCormick read a paper on negro folk-lore in America.

The work of the Folk-lore Society has shown a marked advance of late years. Although the membership has not as much increased as might be desired, the Society has been able to publish, in addition to its journal, a number of supplementary volumes dealing with special subjects, and has thus succeeded in making valuable contributions to the study of American folk-lore. This work is being carried on as energetically as possible, and in the coming year the Society expects to publish two new volumes, one on current superstitions among the English speaking people of North America, by Mrs. Fanny Bergen, and a second one, a full collection of Navahoe myths, by Dr. Washington Matthews. The Society derives much of its support from local societies which are being organized in a great number of the larger cities of our continent, but most of its success is due to the unflinching perseverance of its Secretary, Mr. W. W. Newell.

The officers elected for the coming year, are: Captain John Bourke, President; Mr. Stewart Culin, First Vice-President; Dr. F. Boas, Second Vice-President. The next annual meeting will be held in the Christmas week of this year, in Baltimore, Md.

F. B.

\section{ALASKA AS IT WAS AND IS, 1865-1895. (Concluded.)}

Ar the time of my first visit and until very recently the sole productive industry 